\title{
KARAKTER TOKOH DALAM CERPEN LENGTU LENGMUA KARYA TRIYANTO TROWIKROMO
}

\author{
Afsun Aulia Nirmala \\ Program Studi Pendidikan Bahasa dan Sastra Indonesia. Universitas Pancasakti Tegal. \\ Jalan Halmahera Km. 1 Kota Tegal, Jawa Tengah, Indonesia \\ Email: gendhissastra@yahoo.com.Telp:085640047679.
}

\begin{abstract}
ABSTRAK
Triyanto Triwikromo merupakan seorang penulis kenaan di Indonesia, khususnya di Jawa Tengah. Beliau banyak menghasilkan karya termasuk cerpen Lengtu Lengmua yang banyak memunculkan karakter dengan berbagai ciri khas. Cerpen Lengtu Lengmua adalah sebuah cerpen yang memiliki karakter yang kompleks. Bukan hanya memiliki satu tokoh utama yang fokus, akan tetapi banyak sekali tokoh yang semuanya berperan untuk mengisi "ruh" dalam cerpen ini. bahwa ada empat tokoh yang memiliki karakteristik berbeda sehingga mampu membangun cerita lebih hidup lagi. Empat tokoh di dalam cerpen Lengtu Lengmua antara lain pertama, Kiai Siti yang merupakan tokoh agamais yang sangat sabar, tidak pernah marah. Kedua, Jamuri adalah seorang yang keras kepala. Dia ingin membiakkan celeng di kampungnya. Selain itu, Jamuri adalah tokoh yang sangat licik dan berani bertarung demi keinginannya sendiri. Ketiga, Kufah merupakan seorang gadis kecil yang sangat tergila-gila dengan celeng. Dia kerap kali membayangkan dan berimajinasi tentang celeng. Terkahir adalah Rajab yang merupakan seorang laki-lai yang pemberang berasal dari kampung, akan tetapi dia adalah manusia yang berpendidikan. Rajab ingin sekali menyelamatkan kampungnya dari bahaya celeng. Terkadang sifat provokator juga kerap muncul dalam diri Rajab.
\end{abstract}

Kata kunci: karakter, cerpen

\begin{abstract}
Triyanto Triwikromo is an Indonesian writer, especially in Central Java. He produced many works including the Lengtu Lengmua short story which gave rise to many characters with various characteristics. Lengtu Lengmua Short Story is a short story that has complex characters. Not only has one main character focused, but there are many figures who all have roles to fill in the "spirit" in this short story. that there are four figures who have different characteristics so they are able to build stories more alive. Four figures in the short story Lengtu Lengmua were among others, first, Kiai Siti who was a religious figure who was very patient, never angry. Second, Jamuri is a stubborn person. He wanted to breed wild boars in his village. Besides that, Jamuri is a very cunning character and dares to fight for his own desires. Third, Kufah is a little girl who is very crazy about wild boar. He often imagined and imagined wild boar.

Keywords: character, short story
\end{abstract}




\section{Jurnal Bahasa, Sastra Indonesia, dan Pengajarannya \\ Volume 2- Nomor 1, April 2019, (HIm 171-179) \\ Available online at: http://sasando.upstegal.ac.id}

\section{PENDAHULUAN}

Cerpen merupakan salah satu karya sastra yang sangat simpel dibaca oleh masyarakat Indonesia. Dengan membaca cerpen, waktu yang diperlukan tidak terlalu panjang, karena pada hakikatnya cerpen adalan bacaan sekali duduk, yang artinya dapat dibaca sekilas waktu dan tidak memerlukan waktu yang panjang. Banyak cerpen di Indonesia yang mampu membuat para pembaca belajar dan merenungi setiap kisah-kisahnya. Sepengkal kisah kehidupan manusia yang tertuang dalam berpen akan menjadi sebuah pembelajaran para pembaca. Dalam hal ini diharapkan karya sastra khususnya cerpen dapat memberi sebuah pencerahan kehidupan manusia yang memebaca karya sastra ini.

Sudah banyak karya sastra yang dimuat di media cetak/ elektronik di
Indonesia, salah satu penulis cerpen kenamaan di Indonesia adalah beliau yang telah banyak menulis cerpen-cerpen pilihan dan juga memenangkan sayembara penulisan termasuk di koran Kompas. Cerpen yang dipilih pada penelitian kali ini berjudul Lengtu Lengmua yang menceritakan kehidupan masyarakat di sebuah kampung yang tiba-tiba terkena virus celeng (babi hutan). Dari segi karakter tokoh-tokohnya yang komplek, cerpen ini menggambarkan sifat para manusia yang bermacam ragam.

Oleh karena itu dipilihnya judul karakter tokoh cerpen Lengtu Lengmua Karya Triyanto Triwikromo pada penelitian ini adalah untuk mencari apa saja karakter tokoh dalam sebuah cerpen. Cerpen Lengtu Lengmua adalah sebuah cerpen yang memiliki karakter yang kompleks. Bukan hanya memiliki satu tokoh utama yang fokus, akan tetapi banyak sekali tokoh yang semuanya 


\section{Jurnal Bahasa, Sastra Indonesia, dan Pengajarannya \\ Volume 2- Nomor 1, April 2019, (Hlm 171-179) \\ Available online at: http://sasando.upstegal.ac.id}

berperan untuk mengisi "ruh" dalam

cerpen ini. Karakter adalah sifat-sifat

kejiwaan, akhlak atau budi pekerti

yang membedakan seseorang dengan

yang lain, tabiat atau watak. (Noor

2011 : 47) mengatakan bahwa

karakter tugas perkembangan anak-

anak adalah berkaitan dengan rasa ingin tahu yang tinggi. Anak senang

memuaskan keingintahunnya dengan

hal-hal baru yang berbeda dengan

menjelajahinya.

Anak yang lebih besar ingin menjelajah lebih jauh dari lingkungan rumah dan lingkungan tetangga. Misalnya rumah tua yang tak terpakai dan rumah baru yang sedang dibangun akan membangkitkan minat anak. Anak kota ingin menjelajah desa, sementara anak desa ingin menjelajah lingkungan kota.

Dengan demikian kegiatan menjelajah pada masa akhir kanak- kanak lebih menyenangkan bila dilakukan bersama anak lain. Pada periode ini menjelajah aktivitas yang populer. Popularitas menjelajah sebagai kegiatan bermain menimbulkan banyak kegiatan rekreasi dari kelompok terorganisasi seperti pramuka atau lainnya. Didalam karakter tokoh ada macam-macam teori, teori tersebut dibedakan menjadi dua yaitu teori tentang penokohan dan teori tentang tokoh.

\section{1) Konsep Teori tentang}

\section{Penokohan}

Penokohan itu sendiri merupakan bagian, unsur, yang bersama dengan unsur-unsur yang lain membentuk sebuah totalitas. Penokohan yaitu upaya seorang pengarang dalam menampilkan sebuah gambaran karakter dan watak tokoh, bagaimana mengembangkan dan pembangun tokoh dalam sebuah cerita, biasanya terdiri dari tokoh utama dan 


\section{Jurnal Bahasa, Sastra Indonesia, dan Pengajarannya \\ Volume 2- Nomor 1, April 2019, (HIm 171-179) \\ Available online at: http://sasando.upstegal.ac.id}

tambahan, serta menggunakan teknik-

teknik untuk melukiskan atau watak

tokoh. Penokohan sebagai salah satu

unsur pembangun fiksi dapat dikaji

dan dianalisis keterjalinannya dengan

unsur-unsur pembangun lainya. Jika

fiksi yang bersangkutan merupakan

sebuah karya yang berhasil,

penokohan pasti berjalan secara

harmonis dan saling melengkapi

dengan berbagai unsur lain

(Nurgiyantoro 2013:254).

\section{2) Konsep Teori tentang Tokoh}

Tokoh adalah pelaku cerita

Setiap tokoh memiliki watak atau

karakter setiap tokoh berbeda-beda.

Adapun penokohan adalah cara

pengarang menampilkan tokoh-tokoh

dan watak-wataknya dalam cerita,

watak tokoh dalam cerita dijelaskan

pengarang secara langsung. Tokoh

menunjuk pada orang sebagai pelaku cerita, memaparkan tokoh cerita adalah

orang-orang yang ditampilkan dalam suatu karya naratif atau drama yang oleh pembaca memiliki moral dan kecenderungan tertentu seperti yang diekspresikan dalam ucapan dan apa yang dilakukan dalam tindakan. (Santosa 2011:3)

a. Macam-Macam Tokoh Nurgiyantoro (2005:176)me njelaskan bahwa tokoh-tokoh cerita dalam sebuah fiksi dapat dibedakan dalam beberapa jenis penamaan berdasarkan dari sudut mana penamaan itu dilakukan. Berdasarkan perbedaan sudut pandang dan tinjauan, seorang tokoh dapat dikategorikan ke dalam beberapa jenis penamaan sekaligus. Penamaan tokoh- tokoh tersebut antara lain yaitu tokoh utama dan tokoh tambahan, tokoh protagonis 


\section{Jurnal Bahasa, Sastra Indonesia, dan Pengajarannya \\ Volume 2- Nomor 1, April 2019, (HIm 171-179) \\ Available online at: http://sasando.upstegal.ac.id}

dan tokoh antagonis, tokoh karya Triyanto Triwikromo.

bulat, serta tokoh tipikal dan

Prosedur

tokoh netral. Adapun

Penelitian yang dilakukan dengan

penjelasan macam- macam

menggunakan metode simak catat. Peneliti

tokoh yaitu sebagai berikut.

\section{METODE}

membaca cerpen yang telah diplih kemudian

dibaca dan dicatat karakter yang ada di dalam cerpen tersebut.

Data, Instrumen, dan Teknik

\section{Jenis Penelitian}

enelitian yang digunakan dalam penelitian ini adalah berjenis

\section{PengumpulanData}

deskripsi kulaitatif. Menurut

Summber data dalam penelitian ini adalah teks yang terdapat di dalam cerpen. Teknik Azwar $(2013,5) \quad$ penelitian pengumpulan data yang digunakan dalam dengan pendekatan kualitatif penelitian ini adalah metode simak dengan menekankan pada hasil analisisnya pada proses penyimpulan dengan pola Teknik Analisis Data

deduktif. Dan induktif, Data yang diperoleh kemudian dilakukan pendekatan ini juga lebih analisis berdasarkan analisis isi dengan menekankan pada dinamika melakukan identifikasi dan dirduksi. hubungan antarfenomena yang Adapun penyajian hasil analisis data diamati, dengan menggunakan ditempuh dengan penyajian informal, yaitu logika ilmiah. penyajian dengan kata-kata biasa.

\section{Waktu Penelitian}

Waktu pelaksanaan penelitian ini adalah pada bulan September 2018 s.d. Oktober 2018.

\section{Target/Subjek Penelitian}

Subjek dalam penelitian ini adalah sebuah cerpen yang berjudul Lengtu Lengmua

\section{HASIL DAN PEMBAHASAN}

Dalam pembahasan ini, penulis mendapatkan ada empat tokoh yang memiliki karakter khas, sehingga disa 


\section{Jurnal Bahasa, Sastra Indonesia, dan Pengajarannya \\ Volume 2- Nomor 1, April 2019, (HIm 171-179)}

Available online at: http://sasando.upstegal.ac.id

diuraikan dalam deskripsi di bawah

ini;

\section{Kiai Siti}

Karakter Kiai Siti merupakan

tokoh agamais yang sangat sabar,

tidak pernah marah. Hal ini

dibuktikan dengan kalimat berikut

ini.

"Allah tentu punya maksud

mengapa Dia mengirim celeng-

celeng itu ke sini...," batin Kiai

Siti.

Kiai Siti-yang telah berkali-

kali melihat celeng dan tahu daging satwa itu haram jika dimakan - sebenarnya punya alasan untuk marah. Namun, dia memilih setelah shalat isya saja akan bertemu dengan Jamuri untuk membicarakan celeng-celeng itu.

\section{Jamuri}

\section{Karakter Jamuri adalah}

seorang yang keras kepala. Dia ingin

membiakkan celeng di kampungnya.

Selain itu, Jamuri adalah tokoh yang

sangat licik dan berani bertarung demi keinginannya sendiri. Hal ini dibuktikan

dengan kalimat berikut ini.

Akan tetapi Jamuri, pemilik pembiakan babi liar, tak tinggal diam. Merasa harus menyelamatkan celeng dari amuk manusia, dia berusaha mencari lahan

yang masih memungkinkan dijadikan sebagai daerah hidup binatangbinatang itu. Tak ada tempat lain, dia akhirnya menemukan tanah kosong di ujung tanjung.

Karena itu, setelah membeli tanah dari Lurah Lantip-yang menyerobot tanah milik sebagian warga yang terusir ke tanah relokasi-Jamuri langsung mengusung tujuh celeng betina dan dua celeng jantan ke tanah yang sangat diberkahi oleh Allah ini.

$$
\text { Tetapi menggiring }
$$

sembilan celeng ke ujung tanjung dan melintasi hutan bakau pada senja yang amis bukan perkara mudah. Jamuri dan para cempiang harus berjuang keras menghalau celeng agar tidak berlarian ke laut. Apalagi karena satwa-satwa asing itu jadi tontonan gadis kencur Kufah dan anak-anak kecil lain, perjalanan ke kandang agak terhambat.

Jamuri tak tinggal diam. Dengan mengacung-acungkan parang, ia mengajak sembilan cempiang berbaju loreng meladeni perlawanan Rajab. Perkelahian pun tak terelakkan. Jamuri juga sudah menyusun strategi untuk menghilangkan sang pemberang dari kampung. Jamuri menjebak dan Rajab tak tahu sembilan celeng yang dikawal oleh sembilan cempiang telah mengepungnya malam itu.

2. Kufah

Kufah merupakan seorang gadis kecil yang sangat tergila-gila dengan celeng. Dia kerap kali membayangkan dan 


\section{Jurnal Bahasa, Sastra Indonesia, dan Pengajarannya \\ Volume 2- Nomor 1, April 2019, (HIm 171-179)}

Available online at: http://sasando.upstegal.ac.id

berimajinasi tentang celeng. Ini

dibuktikan dengan kalimat berikut.

$$
\text { Kufah, misalnya, }
$$

berharap bisa menunggang celengceleng ini, membelai taringtaringnya, dan sesekali memandikan hewan yang dia anggap lucu setengah mati itu. Jika diperbolehkan oleh Kiai Siti, dia bahkan rela tidur bersama celengceleng itu di kandang. Malah, Kufah juga yakin tepat tengah malam di kedua bahu celeng itu akan tumbuh sayap sehingga dia dan anak-anak kecil lain bisa menunggang celeng terbang mengelilingi hutan bakau dan mengajak bangau-bangau di kampung itu berkejaran di langit dalam cahaya bulan.

\section{Rajab}

Rajab merupakan seorang laki-lai yang

pemberang berasal dari kampung, akan

tetapi dia adalah manusia yang

berpendidikan. Rajab ingin sekali

menyelamatkan kampungnya dari

bahaya celeng. Terkadang sifat

provokator juga kerap muncul dalam

diri Rajab. Sayangnya di akhir kisah

rajab diceritakan bernasib sial karena

diserang oleh tokoh lain, yaitu Jamuri.

Hal ini dibuktikan dengan kalimat

berikut.
Akan tetapi Rajab, pemuda pemberang yang pernah sekolah di Kota Wali tak

sabar menunggu shalat isya tiba. Menunda shalat magrib dia mengajak beberapa warga melabrak Jamuri. Rajab - karena telah membaca begitu banyak buku perihal celeng_tak ingin kampung yang sangat dia cintai menjadi pemasok hewan yang dianggap sebagai paling rakus, suka mencuri, gemar kawin, dan selalu berisik itu. Dan lebih dari itu, Rajab tak ingin kampung di ujung tanjung ini, menjadi tempat pembiakan celeng. Dia khawatir celeng-celeng itu mendengus-dengus merapalkan semacam mantra pembunuh dan tepat tengah malam satwa-satwa yang telah kerasukan ratusan iblis itu akan menyeruduk seluruh warga dan tak memberi kesempatan mereka untuk mendengarkan lagi keributan kicau bangau dan gesekan daun-daun bakau dengan angin amis yang risau....

Rajab tentu saja tak terima mendengar penjelasan Kiai Siti. Ia mengira Kiai Siti telah disuap Jamuri sehingga berkesan membiarkan pembangunan pusat pembiakan celeng di kampung yang riuh oleh lantunan shalawat dan zikir itu.

Karena itu tanpa permisi dan tak jadi shalat isya, Rajab meninggalkan Kiai Siti. Pemberang yang khatam syariat agama dari Kota Wali ini berusaha mencari cara mengusir para celeng, cempiang, dan Jamuri dari tanah yang dia anggap paling suci ini.

\footnotetext{
"Jamuri ternyata juga celeng. Semalam aku melihat ia berubah jadi celeng. Mula-mula ia merangkak ke arahku..., kemudian mulutnya memanjang berubah jadi moncong berlendir yang

menjijikkan..., dan tumbuh pula sepasang taring yang siap menghunjam perut siapa
}

berbisik dengan mulut yang lebih berbusa lagi. 


\section{Jurnal Bahasa, Sastra Indonesia, dan Pengajarannya \\ Volume 2- Nomor 1, April 2019, (HIm 171-179)}

Available online at: http://sasando.upstegal.ac.id

Dan, masya Allah, tak seorang pun berhasrat mendebat perkataan sang pemberang yang merasa sedang melakukan pekerjaan agung untuk menyelamatkan kampung.

"Jadi tak ada alasan apa pun kita harus menyingkirkan Kiai Siti dan Jamuri. Kita harus mengenyahkan celeng-celeng itu dari kampung ini... Ambil parang, celurit, linggis, bambu runcing, atau apa pun.... Kita serang mereka malam ini juga...."

Lalu malam itu juga Rajab membayangkan diri menjadi Hamzah (panglima perang pasukan Nabi Muhammad dalam Perang Uhud) yang mengomando pertempuran sengit melawan kemungkaran. Dengan bengis dia akan segera menghunjamkan linggis ke perut celeng-celeng itu... dengan bengis dia akan memburaikan usus hewan-hewan menjijikkan itu.

Sayang, pada saat sama Jamuri juga ingin menyingkirkan Rajab. Jamuri juga sudah menyusun strategi untuk menghilangkan sang pemberang dari kampung. Jamuri menjebak dan Rajab tak tahu sembilan celeng yang dikawal oleh sembilan cempiang telah

mengepungnya malam itu. Mereka bersiap-siap menyeruduk dan menancapkan taring ganas ke tubuh rapuh Rajab yang tak berpelindung apa-apa itu. Dengan menyeruduk laki-laki pemberang, mereka ingin Rajab menjadi celeng pertama yang berasal dari kampung penuh harum zikir dan shalawat di kampung itu....

\section{SIMPULAN}

Dalam penelitian ini dapat diambil kesimpulan bahwa ada empat tokoh yang memiliki karakteristik berbeda sehingga mampu membangun cerita lebih hidup lagi. Empat tokoh di dalam cerpen Lengtu Lengmua antara lain pertama, Kiai Siti yang merupakan tokoh agamais yang sangat sabar, tidak pernah marah. Kedua, Jamuri adalah seorang yang keras kepala. Dia ingin membiakkan celeng di kampungnya. Selain itu, Jamuri adalah tokoh yang sangat licik dan berani bertarung demi keinginannya sendiri. Ketiga, Kufah merupakan seorang gadis kecil yang sangat tergila-gila dengan celeng. Dia kerap kali membayangkan dan berimajinasi tentang celeng. Terkahir adalah Rajab yang merupakan seorang laki-lai yang pemberang berasal dari kampung, akan tetapi dia adalah manusia yang berpendidikan. Rajab ingin sekali menyelamatkan kampungnya dari bahaya celeng. Terkadang sifat provokator juga kerap muncul dalam diri Rajab. Sayangnya di akhir kisah rajab diceritakan bernasib sial karena diserang oleh tokoh lain, yaitu Jamuri.

\section{DAFTAR PUSTAKA}

Azwar, Saifudin. 2013. Metode Penelitian. Yogyakarta: Pustaka Pelajar.

Nurgiyantoro, Burhan. 2013, Teori

Pengkajian Fiksi. Yogyakarta:

Gadjah Mada University Press.

Noor, Rohinah M.2011, Pendidikan

Karakter Berbasis

Sastra.Yogyakarta: Ar- Ruzz

Media.

Santosa, Wijaya Heru . 2011, Sastra:

Teori dan Implementasi.

Surakarta:Yuma.

Triyanto. 2012. Lengtu Lengmua. 
https://cerpenkompas.word press.com/2012/03/18/lengt u-lengmua/\#more-1545.

Diakses 7 Agustus 2018.

\section{PROFIL SINGKAT}

Afsun Aulia Nirmala lahir di Brebes

pada tanggal 25 Februari 1986.

Meluluskan pendidikan S2 di

Universitas sebelas Maret pada tahu

2010. Dan aktif mengajar di Prodi

Pendidikan Bahasa dan sastra

Indonesia UPS Tegal dari tahun 2010

hingga sekarang. 